Aim of the study: To check the degree of acceptance of, inclination for, and barriers in genetic testing for gene mutations that increase the risk of breast and ovarian cancers among female residents of Warsaw

Material and methods: This study in volved 562 women between 20 and 77 years of age, all of whom were patients visiting gynaecologists practising in clinics in the City of Warsaw. The studied population was divided into six age categories. The study method was a diagnostic poll conducted with the use of an original questionnaire containing 10 multiple-choice questions. Results: Nearly $70 \%$ of the women showed an interest in taking a test to detect predispositions to develop breast and ovarian cancer. More than $10 \%$ did not want to take such a test, while every fifth women was undecided. No statistically significant differences between the respondents willingness to pay and education were found $(p=0.05)$. The most frequent answer given by women in all groups was that the amount to pay was too high. Such an answer was given by $52.17 \%$ of women with primary education, $65.22 \%$ of women with vocational education, $58.61 \%$ of women with secondary education, and $41.62 \%$ of women with higher education.

Conclusions: Women with a confirmed increased risk of developing breast and/or ovarian cancer due to inter alia the presence of BRCA1 and BRCA2 gene mutations should pay particular attention to $1^{\text {st }}$ and $2^{\text {nd }}$ level prophylaxis.

Key words: breast cancer, prophylaxis, BRCA1, BRCA2.

Contemp Oncol (Pozn) 2016; 20 (1): 80-85 DOI: $10.5114 /$ wo.2016.58504

\section{Acceptance of, inclination for, and barriers in genetic testing for gene mutations that increase the risk of breast and ovarian cancers among female residents of Warsaw}

\author{
Dominik Olejniczak ${ }^{1}$, Paulina Dera ${ }^{1}$, Urszula Religioni², Aneta Duda- \\ Zalewska ${ }^{1}$, Andrzej Deptała ${ }^{1}$
}

1Public Health Division, Medical University of Warsaw, Warsaw, Poland

${ }^{2}$ Collegium of Socio-Economics, Warsaw School of Economics, Warsaw, Poland

\section{Introduction}

The incidence of malignant cancers has been growing in recent years both in Poland and worldwide, and so have the related mortality rates.

Among the methods used for determining increased risk of breast and ovarian cancer is genetic testing for BRCA1 and BRCA2 gene mutations. $B R C A 1$ and $B R C A 2$ are genes whose mutations account for approximately $10 \%$ of genetic cancers.

The occurrence of a mutation within BRCA1 raises the risk of development of breast cancer by $50-80 \%$ and an ovarian cancer by approximately $40 \%$, and with a mutation within BRCA2 by, respectively, 31-56\% and $11-27 \%[1,2]$.

Testing for gene mutations consists of collecting a biological sample from the patient and then amplifying the genetic material with a Polymerase chain reaction $(P C R)$, method. Whether or not a mutation is present is determined on the basis of the test results. The process of collecting the biological material is quick and painless.

In the case of a positive disease history and other overlapping breast and ovarian cancer risk factors, genetic predisposition testing provides a valuable tool for determining the cancer risk level in the patient.

Breast and ovarian cancers are among the leading causes of morbidity and mortality among women around the world. According to GLOBOCAN's estimates, breast cancer holds the first position both in terms of cancer incidence and mortality among women ( $23 \%$ and $12.4 \%$, respectively), while ovarian cancer comes sixth in terms of incidence (4\%) and seventh in terms of mortality (4.2\%) due to malignant cancers in women [3]. In 2012, breast cancer morbidity and mortality in Europe stood at $94 / 10^{5}$ and $23 / 10^{5}$, respectively. The morbidity rate in the EU27 was higher at nearly $109 / 10^{5}$, with the mortality rate slightly lower at an estimated $22 / 10^{5}$. At the same time, the highest rates of morbidity of malignant breast cancers were recorded in Western European countries and Scandinavia, i.e. Finland $\left(211 / 10^{5}\right)$, Belgium $\left(147 / 10^{5}\right)$, Denmark $\left(143 / 10^{5}\right)$, France $\left(137 / 10^{5}\right)$, the Netherlands $\left(131 / 10^{5}\right)$, Iceland $\left(131 / 10^{5}\right)$, and Great Britain $\left(129 / 10^{5}\right)[4]$.

In Poland, the morbidity rate of malignant breast and ovarian cancers among women in 2010 was estimated at $49.6 / 10^{5}$ and $11.3 / 10^{5}$, respectively. At the same time, breast cancer was the most frequently recorded malignant cancer in the female population (22.4\%) and the second-largest cause of cancer-related deaths (12.8\%). On the other hand, ovarian cancer was the fifth most frequent cancer (5.1\%) and fourth largest cause of cancer-related deaths (6.2\%). One should note, however, that analysis of the structure of 
deaths due to female genital organ cancers in Poland indicates that ovarian cancer is the first largest cause of death in that disease group [5].

The National Cancer Registry's forecasts regarding morbidity and mortality of malignant cancers in Poland by 2025 show that the number of women developing breast cancer throughout the forecast period will be growing dramatically to as many as 20,000 per annum. The mortality rate will decrease, however, which will result in a dynamic growth of the population of women living with breast cancer, with the highest increase in incidence observed among women older than 50 years of age and more than $50 \%$ of new cancer cases in women between 50 and 69 years of age. The forecast changes in the ovarian cancer morbidity rate will vary in individual age groups. On the whole, however, the number of cancer cases in the entire population will grow as a result of an increased incidence of ovarian cancer in the oldest age group, i.e. in women older than 65 years of age. It is estimated that in 2025 more than $60 \%$ of new cancer cases will be recorded in women in the oldest age group. The forecast mortality rates for the entire female population also indicate that the growth trend will remain steady at around $0.7 \%$ per annum, and in the oldest age group it is estimated to be nearly $2.3 \%$ per annum [6].

\section{Material and methods}

This study involved 562 women between 20 and 77 years of age, all of whom were patients visiting gynaecologists practising in clinics in the city of Warsaw. The studied population was divided into six age categories. The study method was a diagnostic poll conducted with the use of an original questionnaire containing 10 multiple-choice questions.

Data gathered during the study was processed in STATISTICA v.10 software. With the aim to show relations between independent variables and selected dependent variables, the authors applied a tabular analysis with the use of cross tables in which statistical measures were the numbers and percentages of the answers. Also used in the statistical analysis were verification statistical hypotheses based on Pearson's $\chi^{2}$ test. In addition, the strength of relationships between the variables was assessed with the use of Spearman's rank-order correlation. Differences in all the tests conducted whose likelihood was $p<0.05$ were considered as statistically significant.

\section{Results}

A total of 562 women aged between 20 and 77 years participated in the study. The studied population was divided into three age categories. Patients aged between 40 and 59 years comprised the largest group (Table 1).
The majority of the respondents were women with secondary education (59\%). A large proportion of the women had studied in higher education (Fig. 1).

The group of 562 women was analysed regarding incidence of breast or ovarian cancer in their families (Fig. 2).

Three per cent of respondents in the study group admitted that they had the disease. More than a half of the study subjects (65\%) said that neither breast nor ovarian cancer was or is in their families. $24 \%$ of all the study subjects confirmed cancer among their family members.

There are statistically significant differences between the morbidity rate of breast or ovarian cancers and the respondents' age $\left(\chi^{2}=32.223, p=0.000\right.$; Spearman's $R=0.129, p=0.002$ ). The most numerous group of respondents who either had or have breast or ovarian cancer are women aged $40-59$ years (64.71\% of the women who confirmed the existence of the disease). Women aged 40-59 years most frequently indicated breast or ovarian cancer among members of their families (40.00\% of the answers).

Women aged more than 50 years were asked about taking hormone replacement therapy. Based on the answers received, the authors found that the majority of the study subject do not take hormone replacement therapy ( $85 \%$ of the respondents). In the group that answered affirmatively to that question, the therapy is used mainly by women aged $40-59$ years (60.42\% of all the women), with $\chi^{2}=14.297$ and significance $p=0.000$, and Spearman's $R=0.209$ and significance $p=0.000$

Nearly $35 \%$ of the study subjects admitted to having taken contraceptives before turning 30 years of age. Taking hormone contraceptives was correlated with the respondent's age, education, and incidence of breast or ovarian cancer in their families (Table 2). The most numerous group of subjects who took contraceptives before 30 years of age included women aged $40-59$ years, who answered that no one in their family suffered from breast or ovarian cancer (respectively, $47.95 \%$ and $55.84 \%$ of the women taking contraceptives). No statistically significant relationships between taking contraceptives before 30 years of age and the respondents' education were found ( $p>0.05)$.

The majority of the study subjects (67\%) had heard about genetic testing designed for detecting tendencies to develop breast or ovarian cancer, most of them aged 40-59 years (with $\chi^{2}=218.622$ and level of significance $p=0.000$, and Spearman's $R=0.558$ and level of significance $p=0.000)$. There were no statistically significant differences between the respondents' knowledge of genetic testing and level of education $(p>0.05)$. However, there was a relation between the knowledge of genetic testing and incidence of breast or ovarian cancer among the respondents or their families $\left(\chi^{2}=26.552, p=0.000\right.$; Spearman's $R=0.162, p=0.001) .82 .35 \%$ of the women who have or have had cancer said they knew of the test-

Table 1. Descriptive statistics of the respondents' age

\begin{tabular}{|lccccccc} 
& Average & Min. & Max. & Median & Mode $\begin{array}{c}\text { Frequency } \\
\text { of the mode } \\
\text { deviation }\end{array}$ \\
\hline Respondents' age & 50.75 & 20 & 78 & 51 & 51 & 76 & 13.40
\end{tabular}




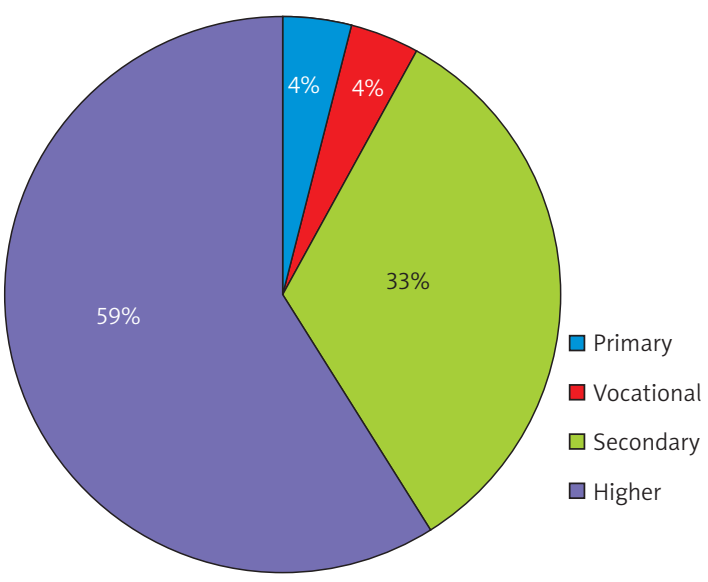

Fig. 1. Respondents' education

Table 2. Taking hormone contraceptives and selected independent variables

\begin{tabular}{lcc}
\hline Independent variable & \multicolumn{2}{c}{ Taking hormone contraceptives } \\
\cline { 2 - 3 } & $p$ value & Spearman's $R^{*}$ \\
\hline Age & 0.000 & -0.576 \\
\hline $\begin{array}{l}\text { Education } \\
\begin{array}{l}\text { Morbidity of breast or } \\
\text { ovarian cancer among } \\
\text { closest relatives }\end{array}\end{array}$ & 0.311 & - \\
\hline
\end{tabular}

only statistically significant correlations were indicated; $p<0.05$

Table 3. Knowledge of genetic testing detecting tendencies to develop breast or ovarian cancer and selected independent variables

\begin{tabular}{lcc} 
Independent variable & \multicolumn{2}{c}{ Knowledge of genetic testing } \\
\cline { 2 - 3 } & $p$ value & Spearman's $R^{*}$ \\
Age & 0.000 & 0.558 \\
Education & 0.141 & - \\
$\begin{array}{l}\text { Morbidity of breast or ovarian } \\
\text { cancer among closest relatives }\end{array}$ & 0.000 & 0.162 \\
\hline
\end{tabular}

*only statistically significant correlations were indicated; $p<0.05$

Table 4. Knowledge of cancer risk factors and selected independent variables

\begin{tabular}{lcc}
\hline Independent variable & \multicolumn{2}{c}{ Knowledge of cancer risk factors } \\
\cline { 2 - 3 } & $p$ value & Spearman's $R^{*}$ \\
Age & 0.000 & 0.429 \\
\hline $\begin{array}{l}\text { Education } \\
\text { Morbidity of breast or ovarian } \\
\text { cancer among closest relatives }\end{array}$ & 0.008 & -0.129 \\
\hline $\begin{array}{l}\text { Taking hormone contraceptives } \\
\text { before the age of } 30 \text { years }\end{array}$ & 0.000 & - \\
\hline
\end{tabular}

*only statistically significant correlations were indicated; $p<0.05$

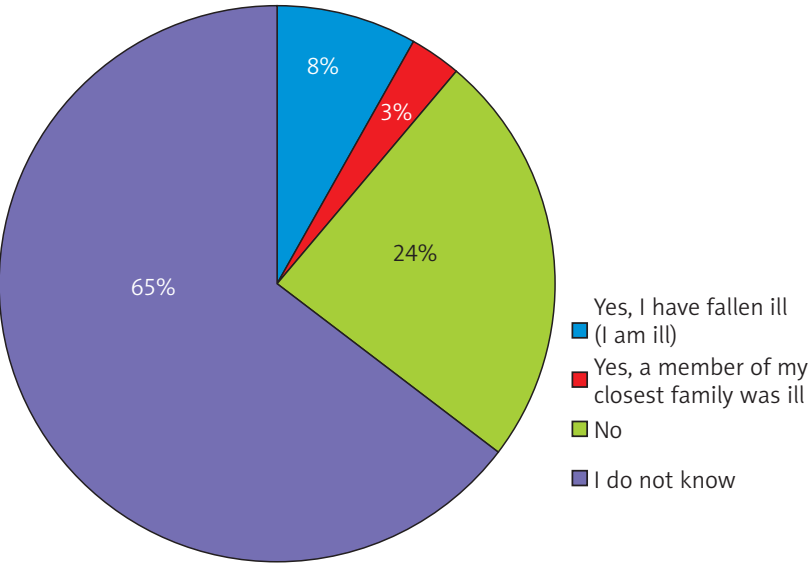

Fig. 2. Have you or any member of your family ever had breast or ovarian cancer?

ing $82.35 \%$, with the figure standing at $86.67 \%$ among the respondents who have a relative with cancer. The results of the correlation of the variables are presented in Table 3.

$87 \%$ of the study subjects listed the following elements as cancer risk factors: cancer history in the family, taking hormone replacement therapy, and taking hormone contraceptives before the age of 30 years.

Knowledge of the risk factors was mentioned by persons aged up to 60 years (nearly 100\% of the respondents from the age groups below 60 years of age) with higher education ( $93.51 \%$ of the group), who had not taken hormone contraceptives before the age of 30 years $(80.55 \%$ of the group). No relationship was found between knowledge of cancer risk factors and morbidity of cancer by the respondent or their closest relative $(p>0.05)$ (Table 4).

More than a half of the respondents regard cancer as a genetic disease. Nearly $30 \%$ of the respondents do not realise the genetic conditions of cancer incidence (Fig. 3). There is a statistical relationship between the answers given and age $\left(\chi^{2}=42.122, p=0.000\right.$; Spearman's $R=0.271$, $p=0.000)$.

Cancer is regarded as a genetic disease mainly by respondents aged $20-39$ years (around $71.85 \%$ of women in that group). Among study subjects above 60 years of age only $37.98 \%$ of women answered that cancer is a genetic disease. There were no statistically significant differences between answers to the question and education $(p>0.05)$ or incidence of cancer in the respondent's family $(p>0.05)$.

Nearly $70 \%$ of the women showed an interest in taking a test to detect predispositions to developing breast and ovarian cancer. More than $10 \%$ did not want to take such a test, while every fifth women was undecided.

The intention to take a genetic test was strongly connected with the respondent's age $\left(\chi^{2}=225.714, p=0.000\right.$; Spearman's $R=0.598, p=0.000)$. All women from the 20-39-years age group indicated that they would like to take the test, while only $33.65 \%$ of woman above 60 years of age agreed to take it. On analysing the respondents' education it is evident that interest in taking the test mainly concerned women with higher education $(83.78 \%$ of the group), while women with vocational education expressed 


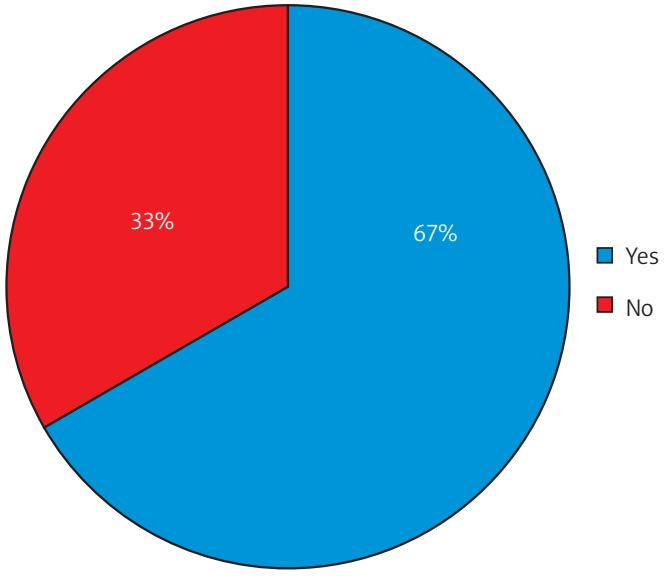

Fig. 3. "Do you think cancer is a genetic disease?"

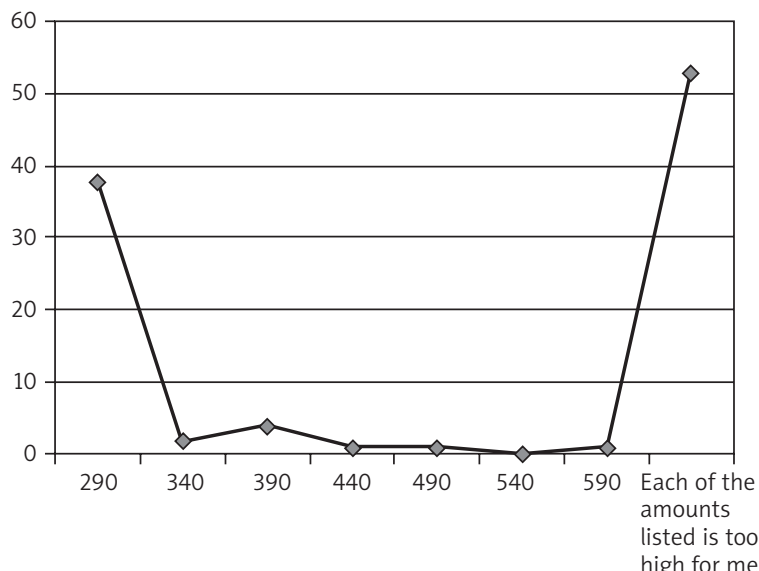

Fig. 4. "What maximum price would you be ready to pay for a test?"

such an interest most rarely (56.52\% of the group). The intention to take the test was expressed particularly often by women who by the age of 30 were taking hormone contraceptives (94.42\% of the group), women who had heard of genetic testing detecting predispositions to develop breast or ovarian cancer ( $80.64 \%$ of the group), and those who said they knew cancer risk factors $(75.26 \%$ of the group) and knew that cancer is a genetic disease (79.61\% of the group). Detailed results of the correlation are shown in Table 5.

The most frequent reason that would make the respondents decide to take genetic testing was being certain of their own risks of developing cancer (48\%). $7 \%$ of the study subjects indicated that there was no reason that would make them take the test (Table 6).

For more than a half of the women who participated in the study, every price of genetic testing was too high to decide to take it. Nearly $40 \%$ of the respondents would be ready to pay up to PLN 290 for a test (Fig. 4).

The readiness to pay only slightly depended on the age $\left(\chi^{2}=76.063, p=0.000\right.$; Spearman's $R=-0.156$, $p=0.000)$ and knowledge of cancer risk factors $\left(\chi^{2}=29.252\right.$,
Table 5. Interest in taking a test detecting predispositions to develop breast or ovarian cancer vs. selected independent variables

\begin{tabular}{lcc}
\hline & \multicolumn{2}{c}{ Interest in taking a test } \\
\cline { 2 - 3 } & $p$ value & Spearman's R* \\
\hline Age & 0.000 & 0.598 \\
\hline Education & 0.008 & -0.190 \\
\hline $\begin{array}{l}\text { Morbidity of breast or ovarian } \\
\text { cancer among closest relatives }\end{array}$ & 0.214 & - \\
\hline $\begin{array}{l}\text { Taking hormone replacement } \\
\text { therapy }\end{array}$ & 0.634 & - \\
\hline $\begin{array}{l}\text { Taking hormone contraceptives } \\
\text { before the age of 30 years }\end{array}$ & 0.000 & -0.407 \\
\hline $\begin{array}{l}\text { Knowledge of the existence of } \\
\text { genetic testing }\end{array}$ & 0.000 & 0.385 \\
\hline $\begin{array}{l}\text { Knowledge of cancer risk factors } \\
\text { Regarding cancer as a genetic } \\
\text { disease }\end{array}$ & 0.000 & 0.388 \\
\hline
\end{tabular}

*only statistically significant correlations were indicated; $p<0.05$ Source: Own research.

Table 6. "What would make you decide to take genetic testing?"

$\begin{array}{lc}\begin{array}{l}\text { Reason } \\ \text { To become certain of my own level of risk of } \\ \text { developing cancer, despite the fact that I am not in } \\ \text { a high-risk group }\end{array} & \begin{array}{c}\text { onswers } \\ \text { ans }\end{array} \\ \begin{array}{l}\text { There have been cases of cancers in my family } \\ \text { Concern for my relatives, e.g. children }\end{array} & 35 \\ \text { (gene damage can be hereditary) } & 31 \\ \begin{array}{l}\text { I have been taking hormone contraceptives } \\ \text { I have been taking/I took hormone replacement } \\ \text { therapy }\end{array} & 14 \\ \begin{array}{l}\text { No reason is important enough for me to take such } \\ \text { a test }\end{array} & 7\end{array}$

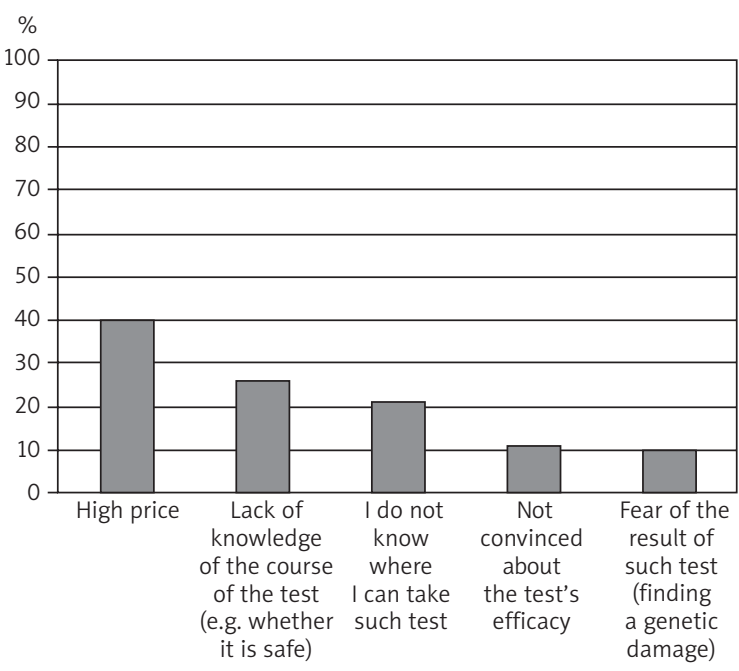

Fig. 5. "What would persuade you to resign from taking such testing (even in the event of a real cancer threat)?" 
$p=0.000$; Spearman's $R=0.118 ; p=0.005$ ). Young women, up to 39 years of age, who indicated that a person from their closest families has cancer, were willing to pay the highest amount for a test. At the same time, nearly $70 \%$ of women above 60 years of age thought that the amounts listed were too high.

No statistically significant differences between the respondents' willingness to pay and education were found $(p=0.05)$. The most frequent answer given by women in all groups was that the amount to pay was too high. Such answer was given by $52.17 \%$ of women with primary education, $65.22 \%$ of women with vocational education, $58.61 \%$ of women with secondary education, and $41.62 \%$ of women with higher education.

The most frequent reason given by the study subjects why they would resign from taking genetic testing, even in the event of a real threat, was the high price of such testing (40\%). Every fifth woman did not know where she could take it. Every tenth person was afraid of the result (Fig. 5).

\section{Discussion}

A method of determining an increased risk of developing particular diseases, genetic testing is still not widespread in Poland, although as many as $66 \%$ of the respondents declared they knew that method of determining the risk. At the same time, only $54 \%$ of the study subjects emphasised that they knew that cancer might have a genetic basis. It is a worryingly low percentage. The lack of such awareness can lead to risky health behaviour consisting of ignoring cancer history in the closest family, and in turn can result in negligence of II level prophylactic actions, which significantly contributes to lowering the chances of recovery in the event of a disease.

A study by Brożek et al. can be used as an example of a study on the impact of hereditary factors, in which the authors unambiguously state that a basic criterion in qualifying for genetic testing towards gene mutations raising the risk of developing breast and ovarian cancer should be the development of cancer in one's family [7].

In this study, speaking of their motivation to take such testing, 35\% of the study subjects declared they would take it because they had cancer cases in their families, while $48 \%$ of the respondents declared their willingness to take such testing although they were not part of the increased risk group. Based on that result, one can say that the respondents who declared their willingness to take the testing despite not being part of the increased group are not fully aware of considerations regarding the use of genetic testing to determine the risk of developing cancer.

A study by Jakubowska et al. can be another example of this line of research. In said study the authors concluded that in Poland's population there is a strong relation between $B R C A 1$ gene mutations and a high relative risk of developing breast cancer [8]. Our own research showed that $31 \%$ of the women indicated their concern for the health of their relatives, e.g. children, as the motivation to take genetic testing.
The price is an important matter in the discussion on the application of genetic testing. Our own research shows that as many as $40 \%$ of the respondents see the high price as an obstacle in undergoing such testing. 38\% of all the study subjects pointed to the proposed price of PLN 290 as an acceptable price they would be ready to pay for such testing. This inspires a discussion on the risk level at which such testing should be reimbursed by the payer and what amount the patient is willing to spend on confirming or ruling out the genetic load. A question arises whether such a price is possible to determine at all, given the risk of developing cancer. In their study conducted on 237 ovarian cancer patients, Lacour et al. also noticed that the cost of genetic testing is one of the main factors in deciding about resigning from taking it. Just as often, these fears are linked with the risk of losing one's health insurance policy at an insurance company or an increased premium paid for such a policy in if the test result is positive [9]. It is worth stressing, however, that the benefits from taking genetic testing are significant and difficult to overestimate. A person with a negative result of genetic testing is informed that the risk of them developing cancer is close to the cancer risk at the entire population's level. Also, a negative result of the test has a favourable impact on the mood of both persons taking it and their relatives. Although it causes universal fear and anxiety among patients, a positive result of genetic testing gives information about the gene mutation carried and the necessity to conduct such testing among relatives. Early identification of the gene mutation permits also starting appropriate prophylaxis for healthy carriers of the mutation and identification of the disease at its early clinical course [10]. Gaj et al. suggest that all women in Poland should be allowed to take inexpensive tests, regardless of their disease histories [11]. The correctness of this solution should be analysed for the cost of such a project, including also the capacity of Poland's health care infrastructure.

It is also essential to develop a help and advice system for women who have been diagnosed with the gene mutations referred to above. Access to genetic counselling and the possibility to use specialist genetic and psychological consultations constitutes the basis for the development of a direct-to-consumer strategy (DTC) [12]. Unfortunately, among female patients the identification of gene mutations alone is wrongly identified with the disease itself - they identify the existence of the mutations with the disease. The importance of genetic counselling in that population group is emphasised by Gronwald [13]. Such education could include the ability to minimise the impact of modifiable risk factors, and could involve convincing women to test themselves for cancerous changes on a more frequent and regular basis. As part of such educational actions, women should not only be informed about locations of genetic clinics where they could take genetic tests, but also about the way the test itself is done. Despite reports about the possibility of genetic testing for BRCA1/BRCA2 gene mutations that have recently been published in the media, nearly $26 \%$ of the respondents involved in this study would resign from it if there were no information regarding the course of the test itself. Meanwhile, a com- 
paratively high percentage (21\%) declared that the immediate reason for them resigning from the test is the lack of knowledge about where oncological genetic clinics are located across the country. Such a situation creates a threat that is related to incomplete cancer risk assessment, which is indeed reduced by the lack of mutation testing.

The importance of genetic counselling, particularly cancer risk assessment, and psychological/social support are also emphasised by Christiant and Pagani [14].

Education associated with the increased cancer risk should also include elements related to cancer therapies, with a particular emphasis on when the disease is diagnosed. Demonstrating the relationship between early cancer detection and the efficacy of the related therapy and chances for recovery can become an element that would motivate women with a higher risk of developing cancers regarding regular testing.

In conclusion: Women with a confirmed increased risk of developing breast and/or ovarian cancer due to inter alia the presence of BRCA1 and BRCA2 gene mutations should pay particular attention to $1^{\text {st }}$ and $2^{\text {nd }}$ level prophylaxis.

Designing an efficient model of conducting genetic testing and developing genetic counselling should be done as part of system-wide solutions that are addressed primarily to women in whom breast and ovarian cancer aggregation has been demonstrated genealogically and clinically. However, construction of said strategies should not ignore women in whose families no cancers have been diagnosed and who spontaneously declare their willingness to take a genetic test.

Introduction of systematic social and educational actions regarding knowledge of factors that can contribute to increasing the cancer risk but also early symptoms indicating the arrival of the disease, as well as the necessity to undergo prophylactic examinations, should constitute an essential elementary determinant for success of population health programmes. The actions in question should particularly include subjects related to breast and ovarian cancers.

It seems substantiated to create a system of support for women among whom an increased risk of breast and ovarian cancer is observed (due to inter alia the presence of gene mutations). Professional psychological counselling should focus primarily on building a positive and pragmatic approach to genetic test results, creating appropriate adaptive conditions for stressful situations that accompany the diagnostic process and identifying patients who require special support.

The authors declare no conflict of interest.

\section{References}

1. Anglian Breast Cancer Study Group. Prevalence and penetrance of BRCA1 and BRCA2 in a population based series of breast cancer cases. Br J Cancer 2000; 83: 1301-8.

2. Ford D, Easton DF, Stratton M, et al. Genetic heterogeneity and penetrance analysis of the BRCA1 and BRCA2 genes in breast cancer families. Am J Hum Genet 1998; 62: 676-89.
3. Ferlay J, Shin HR, Bray F, Forman D, Mathers C, Parkin DM. GLOBOCAN 2008 v2.0, Cancer incidence and mortality worldwide: IARC CancerBase No. 10 [Internet]. Lyon, France: International Agency for Research on Cancer; 2010. Access: http://globocan.iarc.fr [updated 15/10/2013].

4. Ferlay J, Steliarova-Foucher E, Lortet-Tieulent J, Rosso S, Coebergh JW, Comber H, Forman D, Bray F. Cancer incidence and mortality patterns in Europe: Estimates for 40 countries in 2012. Eur J Cancer 2013; 49: 1374-403.

5. Wojciechowska U, Didkowska J, Zatoński W. Nowotwory złośliwe w Polsce w 2010 roku. Wyd. Centrum Onkologii, Warszawa; 2012; 13-15.

6. Didkowska J, Wojciechowska U, Zatoński W. Prognozy zapadalności i umieralności na nowotwory złośliwe w Polsce do 2025 roku. Wyd. Centrum Onkologii, Warszawa 2009; 13-15; 18, 45, 63, 97.

7. Brożek I, Ratajska M, Piątkowska M, et al. Limited significance of family history for presence of BRCA1 gene mutation in Polish breast and ovarian cancer cases. Fam Cancer 2012; 11: 351-4.

8. Brożek I, Cybulska C, Ratajska M, et al. Prevalence of the most frequent BRCA1 mutations in Polish population. J Appl Genetics 2011; 52: 325-30.

9. Lacour RA, Daniels MS, Westin SN, et al. What women with ovarian cancer think and know about genetic testing. Gynecol Oncol 2008; 111: 132-6.

10. Carroll JC, Cremin C, Allanson J, et al. Hereditary breast and ovarian cancers. Can Fam Physican 2008; 54: 1691-2.

11. Gaj P, Kluska A, Nowakowska D, Bałaban A, Piątkowska A, Dabrowska M, Niwińska A, Ostrowski J. High frequency of BRCA1 founder mutations in Polish women with nonfamilial breast cancer. Fam Cancer 2012; 11: 623-8.

12. Ng PC, Murray SS, Levy S, Venter JC. An agenda for personalized medicine. Nature 2009; 461: 724-6.

13. Gronwald J. Wybrane aspekty poradnictwa genetycznego u nosicielek mutacji genu BRCA1. Roczniki Pomorskiej Akademii Medycznej w Szczecinie. Supl. 2006; 107; 1427-4930.

14. Christinat A, Pagani O. Practical aspects of genetic counseling in breast cancer: Lights and shadows. Breast 2013; 22: 375-82.

\section{Address for correspondence}

\section{Dominik Olejniczak}

Public Health Division

Medical University of Warsaw

Banacha 1 A

02-097 Warsaw, Poland

e-mail: dominikolejniczak@op.pl

Submitted: 24.02 .2014

Accepted: $\quad 20.07 .2015$ 